\title{
Management of hyperhidrosis
}

This article was published in the following Dove Press journal:

Clinical, Cosmetic and Investigational Dermatology

29 October 2014

Number of times this article has been viewed

\section{Anna-Bianca Stashak' Jerry D Brewer ${ }^{2}$}

'Internal Medicine Residency Program, Loma Linda University Medical Center, Loma Linda, CA, USA;

${ }^{2}$ Division of Dermatologic Surgery,

Department of Dermatology, Mayo

Clinic, Rochester, MN, USA
Correspondence: Jerry D Brewer

Division of Dermatologic Surgery,

Department of Dermatology,

Mayo Clinic, 200 First Street SW,

Rochester, MN 55905, USA

Tel +l 5072843579

Fax + I 5072842072

Email brewer.jerry@mayo.edu

Abstract: Primary hyperhidrosis $(\mathrm{HH})$, a condition of sweating in excess of thermoregulatory requirements, affects nearly $3 \%$ of the US population and carries significant emotional and psychosocial implications. Unlike secondary $\mathrm{HH}$, primary $\mathrm{HH}$ is not associated with an identifiable underlying pathology. Our limited understanding of the precise pathophysiologic mechanism for $\mathrm{HH}$ makes its treatment particularly frustrating. However, a wide array of interventions for the treatment of $\mathrm{HH}$ have been implemented throughout the world. Herein, we discuss the most extensively studied therapeutic options for primary $\mathrm{HH}$, including systemic oxybutynin, botulinum toxin injections, skin excision, liposuction-curettage, and sympathotomy/sympathectomy. We conclude with a discussion of possible future therapies for $\mathrm{HH}$, including the applications of laser, microwave, and ultrasound technologies.

Keywords: primary hyperhidrosis, secondary hyperhidrosis, eccrine ducts, botulinum toxin, surgery, laser

\section{Introduction}

Hyperhidrosis $(\mathrm{HH})$ is a condition characterized by sweating in excess of what is required for normal thermoregulation. ${ }^{1,2}$ With a prevalence of approximately $2.8 \%$ of the US population ( $1.4 \%$ axillary and $0.5 \%$ palmar, by national survey), ${ }^{3} \mathrm{HH}$ is an often overlooked disorder that has significant impact on psychosocial functioning of affected patients. ${ }^{4-6} \mathrm{~A}$ family history is often reported by patients affected by $\mathrm{HH}$, supporting a basis of genetic transmission that has been explored by Ro et $\mathrm{al}^{7}$ in a recent study. ${ }^{2}$ Although the greatest prevalence of primary $\mathrm{HH}$ is found among individuals aged 25-64 years, the age of onset is likely influenced by affected body region. ${ }^{8}$ Males and females appear to be affected equally. ${ }^{8}$ The purpose of this article is to present an up-todate review of some of the therapies available for $\mathrm{HH}$, including oxybutynin, botulinum toxin (Btx) injections, skin excision, liposuction-curettage (LC), and sympathotomy/ sympathectomy. We will also present some new and emerging treatments. Topical therapies and isolated iontophoresis will not be discussed in this article.

\section{Classification of $\mathrm{HH}$}

$\mathrm{HH}$ is broadly classified into two categories: primary $\mathrm{HH}$ and secondary $\mathrm{HH}$. The diagnosis of primary $\mathrm{HH}$, which is, by definition, not associated with an underlying condition, requires that other (potentially more serious) causative pathologies be ruled out. ${ }^{4}$ Secondary $\mathrm{HH}$, in contrast, may be attributed to a number of other conditions, including endocrine disturbances, drugs, certain malignancies, and central nervous system abnormalities. ${ }^{4} \mathrm{HH}$ can be further distinguished by anatomic distribution of affected regions and by laterality: unilateral versus bilateral and symmetrical. ${ }^{4} \mathrm{HH}$ that 
affects numerous parts of the body is termed "generalized", whereas "focal hyperhidrosis" refers to excessive sweating in a local, bilateral, and symmetrical distribution. ${ }^{2}$

\section{Pathophysiology}

The regions affected in $\mathrm{HH}$ correspond with areas of greatest density of eccrine and apoeccrine ${ }^{9}$ sweat glands - axillae, palms, soles, and face ${ }^{2}$ - with axillary $\mathrm{HH}$ being most common (1.4\% of the US population), ${ }^{10}$ followed by palmar $\mathrm{HH}$ ( $0.5 \%$ of the US population). ${ }^{10}$ The adrenergically stimulated apocrine glands, which have a different distribution from eccrine glands, have not been demonstrated to contribute to $\mathrm{HH} .^{2}$ Whereas apocrine glands produce a more viscous, lipidbased secretion, eccrine glands secrete a watery hypotonic solution upon cholinergic stimulation. ${ }^{2} \mathrm{HH}$ is believed to be caused by overactive cholinergic input to the eccrine glands, ${ }^{11}$ rather than by a defect of the gland apparatus, as histological examination of HH patients' eccrine glands does not exhibit abnormalities such as gland hypertrophy or hyperplasia compared with those of individuals not affected by HH. ${ }^{2}$

Normal thermoregulatory mechanisms are centrally controlled through the anterior hypothalamus. ${ }^{10,12}$ Sweating associated with primary $\mathrm{HH}$ may be related to a dysfunction of the sympathetic nervous system and hypothalamus, coupled with input from the anterior cingulate cortex ${ }^{10}$ of the limbic system, ${ }^{13,14}$ possibly explaining the relationship between certain stimuli (such as emotions) and exacerbation of HH symptom manifestation. ${ }^{10}$ Recent research involving the immunohistochemical analysis of sympathetic ganglia of $\mathrm{HH}$ patients versus organ donor controls without history of $\mathrm{HH}$ demonstrates significantly higher expression of acetylcholine receptors $(P<0.001)$ and significantly larger sympathetic chain ganglia $(P<0.001)$ in the former group. ${ }^{15}$ These fascinating findings by de Moura Júnior et $\mathrm{al}^{15}$ may elucidate a more concrete pathophysiologic explanation for $\mathrm{HH}$.

\section{Assessment of disease severity}

Objective assessment of $\mathrm{HH}$ severity and surface area affected can be performed with a variety of methods, including the Minor's starch iodine test with gravimetric analysis, ${ }^{10}$ dynamic sudorometry, ${ }^{16,17}$ thermoregulatory sweat test, ${ }^{10}$ and skin conductance (SC). ${ }^{14}$

A subjective scale introduced by the Canadian Hyperhidrosis Advisory Committee, the Hyperhidrosis Disease Severity Scale (HDSS), allows patients to characterize the severity of their $\mathrm{HH}$ on a scale from 1 to $4 .{ }^{11,18,19}$ This scale is useful for assessment of relative improvement with therapy. Whereas a one-point improvement corresponds with approximately $50 \%$ reduction in perspiration, a two-point improvement corresponds with roughly $80 \%$ reduction. ${ }^{18}$ Other subjective tools include the Dermatology Life Quality Index (DLQI) ${ }^{11,20}$ and visual analog scale (VAS). ${ }^{14}$

\section{Treatment of $\mathbf{H H}$ Oxybutynin}

Because of the risks associated with surgical treatment of $\mathrm{HH}$ (eccrine gland resection, endoscopic thoracic sympathectomy [ETS], or video-assisted thoracic sympathectomy [VATS] $)^{21}$ and the possibility of compensatory hyperhidrosis (CH) after sympathectomy, oral anticholinergic medications present an appealing option. ${ }^{22}$ Oxybutynin, an anticholinergic oral medication used for conditions such as overactive bladder, ${ }^{22}$ has been employed in a number of cases for the treatment of $\mathrm{HH}^{21-26}$ Wolosker et $\mathrm{al}^{22}$ recently evaluated patient satisfaction with oxybutynin versus placebo for the treatment of palmar, plantar, and axillary $\mathrm{HH}$ in a randomized, single-blinded trial of 50 patients (five of whom were lost to follow-up). Dosing schedule started at $2.5 \mathrm{mg}$ daily for the first week, then $2.5 \mathrm{mg}$ twice daily from days 8 to 21 and $5 \mathrm{mg}$ twice daily starting at day 22. Significantly greater subjective improvement was seen in the oxybutynin groups compared with the placebo groups for palmar, axillary, and plantar $\mathrm{HH}$. More than $70 \%$ of patients in the oxybutynin group treated for palmar or axillary $\mathrm{HH}$ noted significant improvement, whereas only $27.3 \%$ of the corresponding placebo group had moderate improvement $(P<0.001) .^{22}$ More than $90 \%$ of the oxybutynin-treated plantar $\mathrm{HH}$ patients achieved moderate or great improvement, whereas only $13.4 \%$ of the placebo-treated plantar HH group demonstrated moderate improvement $(P<0.001)$. Quality of life (QOL) before and after treatment was also evaluated in the two patient groups. All patients reported poor to very poor QOL before treatment commenced. After treatment, oxybutynin resulted in significantly improved QOL (73.8\%) compared with placebo (13.6\%) across the three anatomical HH groups $(P<0.001) .^{22}$

A subsequent study conducted over a period of 6 years by Wolosker et $\mathrm{al}^{21}$ sought to evaluate the long-term effects of oxybutynin in 431 patients with axillary HH. A similar dosing schedule was employed. Ultimately, of the original 431 patients, only 181 patients were evaluated for more than 6 months, with 34 patients lost to follow-up on first visit and others failing to improve with oxybutynin after 6 weeks who were then referred for VATS (114). ${ }^{21}$ Twenty-six patients demonstrated positive results with oxybutynin treatment after 6 weeks but were referred for VATS due to unwillingness 
to remain on medication long-term. Six patients stopped treatment due to side effects. A final subset of patients (62) are currently undergoing oxybutynin treatment but are not included in the results of this study, as duration of therapy is currently $<6$ months. Of the 181 patients (129 female and 52 male) treated for at least 6 months with oxybutynin, $93.4 \%$ reported improvement at 6 weeks, while $82.9 \%$ of patients maintained substantial improvement after 24 weeks. ${ }^{21}$ When the investigators compared the level of improvement at 6 weeks and at final evaluation (median of 17 months), $57.4 \%$ of patients maintained the original level of improvement, while $23.3 \%$ further improved and $19.4 \%$ reported degradation of symptom resolution $(P<0.001){ }^{21}$

Although a number of studies have demonstrated shortand long-term efficacy of oxybutynin in the treatment of primary $\mathrm{HH}$, the anticholinergic side effects and requirement for chronic pharmacologic therapy limit the use of this medication for some patients. Dry mouth, headache, constipation, and urinary retention ${ }^{26}$ are relatively minor side effects seen with oxybutynin, particularly when daily dose exceeds $15 \mathrm{mg} .{ }^{21}$ For those patients uncomfortable with long-term reliance on pharmacologic therapy for $\mathrm{HH}$, sympathectomy may provide a more appealing option. Wolosker et $\mathrm{al}^{21}$ also suggest that for those patients in whom side effects are intolerable or who fail to improve over 6 weeks (considered oxybutynin failure), sympathectomy or other treatment may be considered. Please see Table 1 for a summary of treatment options.

\section{Botulinum toxin}

The highly potent Btx, derived from Clostridium botulinum, has been employed in a number of medical settings, including minimizing the appearance of facial wrinkles, treatment of cervical dystonia and movement disorders, and alleviation of hypersalivation and HH. ${ }^{27-31}$ By inhibiting the release of acetylcholine from presynaptic cholinergic neurons, Btx effectively produces paralysis at the neuromuscular junction and similarly inhibits sweat secretion by "chemical denervation". ${ }^{11}$ Although there are seven different Btx subtypes $(A-G),{ }^{27}$ two in particular have been studied for use in humans: Btx A, which cleaves the SNAP-25 SNARE protein, and Btx B, which cleaves the VAMP SNARE protein. ${ }^{20}$ Without these anchoring proteins, synaptic vesicles carrying acetylcholine cannot dock to release the contents into the synapse via exocytosis. ${ }^{32-34}$

Recognizing the previous evidence of Btx's effects on sympathetic cholinergic fibers of animals' sweat glands, Bushara and Park ${ }^{35}$ examined the neurotoxin's anhidrotic effects on patients treated with Btx injections for facial spasm.
In a small study of three adult patients, the investigators confirmed regions of anhidrosis corresponding with the regions and sides of the faces that received injections. ${ }^{35}$ In a subsequent study, Bushara et $\mathrm{al}^{36}$ proceeded to demonstrate the anhidrotic effects of Btx injections in seven healthy patients as well. Since that time, numerous studies have demonstrated effective treatment of axillary, palmar-plantar, and craniofacial $\mathrm{HH}$ with Btx injections.

In a recent study of 84 patients with primary focal $\mathrm{HH}$ treated with intracutaneous Btx injections, Rosell et al ${ }^{20}$ demonstrated patient satisfaction of both axillary and palmar $\mathrm{HH}$ treatment. Axillary HH was treated with Xeomin (Btx A) and palmar $\mathrm{HH}$ with both Xeomin and Neurobloc (Btx B). Because of its less significant effects on muscle strength, $\mathrm{Btx} \mathrm{B}$ is useful for palmar $\mathrm{HH}$ where there is concern for development of muscular weakness of the hands. On a scale from 1 to 5 , where " 1 " corresponds to no effect and " 5 " with "satisfied and completely dry", all palmar $\mathrm{HH}$ patients ranked treatment as either 4 or 5 , and $95 \%$ of axillary $\mathrm{HH}$ patients were also satisfied with treatment. ${ }^{20}$ At 3 weeks follow-up, both the palmar and axillary $\mathrm{HH}$ patient groups also demonstrated significant improvement of DLQI scores with treatment: axillary $12.0 \pm 5.5$ to $1.7 \pm 2.6$ and palmar $10.3 \pm 7.0$ to $1.2 \pm 1.5$ ( $P<0.05$ for both groups $){ }^{20}$

In an Italian study of 32 patients by Basciani et al, ${ }^{37}$ the efficacy and safety of Btx B in the treatment of palmar $\mathrm{HH}$ were evaluated. Baseline sweating levels were ascertained through the Minor's iodine starch test with weight measurement. The same tests were also performed at 4 , 12, and 24 weeks after Btx B injections. After injection of 5,000 IU of Btx B into each palm, reduction of sweating levels from baseline at 4, 12, and 24 weeks in both the right and left palms was statistically significant: right palm $2.9 \pm 1.4,0.3 \pm 0.4,0.9 \pm 0.8$, and $2.1 \pm 1.5 \mathrm{~g}(P<0.001)$, left palm $2.8 \pm 1.7,0.5 \pm 0.6,0.8 \pm 0.7$, and $1.8 \pm 1.25 \mathrm{~g}(P<0.001)$, respectively. Adverse effects such as local pain and hand weakness were seen in $12.5 \%$ of patients and were considered minor.

Since the use of Btx for $\mathrm{HH}$ began, there have been numerous studies demonstrating the effectiveness of this treatment for primary HH. ${ }^{1,11,20,27,29,37-40}$ However, because primary $\mathrm{HH}$ is a chronic condition, questions about longevity of treatment efficacy remain. ${ }^{37}$ In a French study of 83 patients with primary axillary $\mathrm{HH}$, Lecouflet et $\mathrm{al}^{38}$ demonstrated increased duration of efficacy of Btx A injections with repetition. Over a period just short of 11 years, the patients were treated with $125 \mathrm{U}$ of Btx A intradermal injections per axillae, and the duration of results of the first and 
Table I Summary of studies and treatments

\begin{tabular}{|c|c|c|}
\hline Study & Description & Findings \\
\hline \multicolumn{3}{|l|}{ Oxybutynin } \\
\hline \multirow[t]{4}{*}{ Wolosker et $\mathrm{al}^{22}$} & Brazil & Significantly greater subjective improvement in oxybutynin group \\
\hline & Oxybutynin vs placebo & $(P<0.001)$ \\
\hline & Palmar, plantar, axillary $\mathrm{HH}$ & \\
\hline & 50 total patients, 5 lost to follow-up & \\
\hline \multirow[t]{5}{*}{ Wolosker et $\mathrm{al}^{21}$} & Brazil & At 6 weeks: $93.4 \%$ subjective improvement \\
\hline & Effects of oxybutynin over 6 years & At 24 weeks: $82.9 \%$ continued substantial improvement \\
\hline & Axillary $\mathrm{HH}$ & Over median of 17 months: $57.4 \%$ maintained same level of \\
\hline & I8I of 431 patients evaluated long-term & improvement; $23.3 \%$ further improved; $19.4 \%$ experienced some \\
\hline & & degree of relapse $(P<0.00 I)$ \\
\hline \multicolumn{3}{|r|}{ - 0} \\
\hline \multirow[t]{4}{*}{ Bushara and Park ${ }^{35}$} & Observed anhidrotic effect of Btx injections for & Correlation between regions of injections with regions of relative \\
\hline & facial spasm & anhidrosis \\
\hline & Craniofacial HH & \\
\hline & 3 adult patients & \\
\hline \multirow[t]{6}{*}{ Bushara et $\mathrm{al}^{36}$} & USA & Day 2: complete anhidrosis dorsal hand (effect persisted II months) \\
\hline & Observed anhidrotic effects of Btx A injections & Day 3: 2/5 axillae completely dry, I/5 axillae demonstrated $\downarrow$ sweating \\
\hline & Palmar, axillary $\mathrm{HH}$ & (effect persisted 6-8 months), 2/5 axillae demonstrated no effect \\
\hline & 7 healthy patients: 2 patients Btx $A$ injections into & \\
\hline & dorsal hand; 5 patients Btx $\mathrm{A}$ injections into & \\
\hline & one axillae & \\
\hline \multirow[t]{7}{*}{ Rosell et $\mathrm{al}^{20}$} & Sweden & Palmar HH group: $100 \%$ patients either 4 or 5 \\
\hline & Btx A (Xeomin) and Btx B (Neurobloc) injections & Axillary $\mathrm{HH}$ group: 95\% satisfied \\
\hline & for palmar $\mathrm{HH}$ & Significant DLQI improvement in both groups at 3 weeks $(P<0.05)$ \\
\hline & Btx $\mathrm{A}$ (Xeomin) injections for axillary $\mathrm{HH}$ & \\
\hline & Patients ranked treatment effects from I & \\
\hline & (no effect) to 5 (completely dry) & \\
\hline & Assessed DLQI & \\
\hline \multirow[t]{6}{*}{ Basciani et $\mathrm{a}^{37}$} & Italy & Significant $\downarrow$ sweating both palms $(P<0.00 \mathrm{I})$ \\
\hline & Btx $B$ injections & Side effects: local pain, hand weakness \\
\hline & Palmar $\mathrm{HH}$ & \\
\hline & Minor's starch iodine and weight measurement & \\
\hline & (baseline and at 4,12 , and 24 weeks after & \\
\hline & injection) & \\
\hline \multirow[t]{7}{*}{ Lecouflet et $\mathrm{al}^{38}$} & France & Duration of efficacy of injections significantly $\uparrow$ with time $(P<0.0002)$ \\
\hline & Btx $\mathrm{A}$ injections & Median duration of effect: first injection 5.5 months; last injection \\
\hline & Assess safety and duration of efficacy with & 8.5 months \\
\hline & repeated injections & \\
\hline & Axillary $\mathrm{HH}$ & \\
\hline & 83 patients & \\
\hline & Approximately II years & \\
\hline \multirow[t]{7}{*}{ Lecouflet et $\mathrm{al}^{41}$} & France & Duration of efficacy of injections significantly $\uparrow$ with time $(P<0.0002)$ \\
\hline & Btx $\mathrm{A}$ injections & Median duration of effect: from first injection 7 months; from last \\
\hline & Assess safety and duration of efficacy with & injection 9.5 months \\
\hline & repeated injections & \\
\hline & Palmar $\mathrm{HH}$ & \\
\hline & 28 patients & \\
\hline & Approximately II years & \\
\hline \multicolumn{3}{|l|}{ Surgery } \\
\hline \multicolumn{3}{|l|}{ Local excision } \\
\hline Heidemann & Denmark & Symptom recurrence more common with local skin excision (5I\% vs \\
\hline \multirow[t]{5}{*}{ and Licht ${ }^{64}$} & Thoracic sympathotomy vs local skin resection & $5 \% ; P<0.001)$ \\
\hline & Axillary $\mathrm{HH}$ & Significantly better symptom resolution with local skin excision \\
\hline & 96 patients & $(P<0.00 \mathrm{I})$ \\
\hline & Median follow-up 26 months & Significantly less $\mathrm{CH}$ and gustatory sweating with local skin excision \\
\hline & Questionnaire (returned by $92 \%$ of patients) & ( $25 \%$ vs $84 \%$ and $26 \%$ vs $54 \%$, respectively; $P=0.01$ ) \\
\hline \multicolumn{3}{|r|}{$e^{\circ}$} \\
\hline \multirow[t]{2}{*}{ Wollina et $\mathrm{al}^{49}$} & Germany & Relapse rate at 12 months $\rightarrow$ \\
\hline & Local skin excision + SQ curettage vs tumescent LC & LC group: I6.2\%; excision + curettage group: I.0\% $(P<0.0 \mathrm{I})$ \\
\hline
\end{tabular}


Table I (Continued)

\begin{tabular}{|c|c|c|}
\hline Study & Description & Findings \\
\hline & Axillary $\mathrm{HH}$ & $\begin{array}{l}\text { Pain } \rightarrow \text { LC group: } 89.2 \% \text { pain free; excision + curettage group: } 24.0 \% \\
\text { pain free }(P<0.0 I)\end{array}$ \\
\hline & I63 patients total: 37 patients received LC, & Complications in LC group: mild hematoma, suture-associated \\
\hline & I 25 patients received excision with SQ curettage & irritation \\
\hline & Minor's starch iodine test and subjective scale & $\begin{array}{l}\text { Complications seen only in the excision }+ \text { curettage group: } \uparrow \text { time } \\
\text { required for healing, wound infections, bleeding }\end{array}$ \\
\hline & & $\begin{array}{l}\text { Other benefits of LC group: } \downarrow \text { time to return to work, more } \\
\text { aesthetically sensitive scars }\end{array}$ \\
\hline \multirow[t]{5}{*}{ Tronstad et al ${ }^{14}$} & Norway & LC group $\rightarrow$ significantly lower SC $(P=0.01 \mathrm{I})$, gravimetric \\
\hline & Isolated curettage vs LC & measurements $(P=0.028)$; better VAS scores for sweating $(P<0.0 \mathrm{I})$ \\
\hline & Axillary $\mathrm{HH}$ & \\
\hline & 22 patients total, 5 lost to follow-up & \\
\hline & SC, gravimetric measurement, VAS & \\
\hline \multirow[t]{5}{*}{ Ibrahim et a ${ }^{55}$} & USA & At 3 months: no significant difference between $L C$ and $B t x A$, but \\
\hline & LC vs Btx A injections & "heavy sweaters" experienced significantly greater relief from Btx A \\
\hline & Axillary $\mathrm{HH}$ & than from LC $(P=0.0025)$ \\
\hline & 20 patients & At both 3 and 6 months: greater satisfaction, more improved QOL \\
\hline & Follow-up at 3 and 6 months & with $B t x(P=0.0002)$ than with LC $(P=0.0017)$ \\
\hline \multicolumn{3}{|c|}{ Sympathectomy and sympathotomy } \\
\hline \multirow[t]{4}{*}{ Bell et $a^{63}$} & Australia & Significant improvement in all 3 groups $(P<0.00 \mathrm{I})$ : $97 \%$ palmar $\mathrm{HH}$ : \\
\hline & ETS efficacy, adverse events & $97 \%, 93 \%$ craniofacial, $71 \%$ axillary \\
\hline & Palmar, axillary, and/or craniofacial $\mathrm{HH}$ & $\mathrm{CH}$ developed in $75 \%$ of patients \\
\hline & 210 patients total, 19 lost to follow-up & $\begin{array}{l}\text { Rates of severe } \mathrm{CH} \text { : craniofacial } 44.5 \% \text {, axillary } 26 \% \text {, palmar } 8 \% \\
(P=0.0003)\end{array}$ \\
\hline \multirow[t]{5}{*}{ Atkinson et $\mathrm{a}^{57}$} & USA & Percent improvement of sweating $>3$ months postoperatively: $96.6 \%$ \\
\hline & Endoscopic thoracic limited sympathotomy & palmar; $69.2 \%$ axillary; $39.8 \%$ plantar \\
\hline & (TI, T2 ganglia spared) & Long-term: palmar $\mathrm{HH}$ recurrence in 5 patients, severe $\mathrm{CH}$ in \\
\hline & Palmar, axillary, plantar $\mathrm{HH}$ & 2 patients ( $1.3 \%)$ \\
\hline & 155 patients & \\
\hline \multirow{6}{*}{$\begin{array}{l}\text { Heidemann } \\
\text { and } \text { Licht }^{64}\end{array}$} & Denmark & Symptom recurrence more common with local skin excision ( $51 \%$ vs $5 \%$; \\
\hline & Thoracic sympathotomy vs local skin resection & $P<0.00 I)$ \\
\hline & Axillary $\mathrm{HH}$ & Significantly better symptom resolution with local skin excision \\
\hline & 96 patients total, $8 \%$ lost to follow-up & $(P<0.001)$ \\
\hline & Median follow-up 26 months & Significantly less $\mathrm{CH}$, gustatory sweating with local skin excision \\
\hline & Questionnaire (returned by $92 \%$ of patients) & ( $25 \%$ vs $84 \%$ and $26 \%$ vs $54 \%$, respectively; $P=0.0 \mathrm{I}$ ) \\
\hline \multirow[t]{5}{*}{ Lesèche et $\mathrm{a}^{169}$} & France & No significant difference in incidence and severity of $\mathrm{CH}$ with respect \\
\hline & Relationship between extent of sympathectomy & to degree of sympathectomy \\
\hline & (2-5 levels) and $\mathrm{CH}$ occurrence & \\
\hline & Palmar and/or axillary $\mathrm{HH}$ & \\
\hline & I34 patients & \\
\hline \multirow[t]{4}{*}{ Yuncu et $\mathrm{al}^{66}$} & Turkey & $100 \%$ of patients (both groups) experienced both immediate and I-year \\
\hline & Isolated T3 vs T3 + T4 sympathectomy & duration of $\mathrm{HH}$ resolution \\
\hline & Axillary $\mathrm{HH}$ & At I-year follow-up: significantly more $\mathrm{CH}$ in $\mathrm{T} 3+\mathrm{T} 4$ group than in \\
\hline & 60 patients & isolated T3 group ( $100 \%$ vs $79 \% ; P=0.008$ ) \\
\hline \multirow[t]{5}{*}{ Yang et $\mathrm{al}^{70}$} & People's Republic of China & Resolution of palmar $\mathrm{HH}$ in all patients (both groups) \\
\hline & Palmar $\mathrm{HH}$ & No recurrence at mean follow-up $13.8 \pm 6.2$ months \\
\hline & I63 patients total: 78 patients underwent & $\mathrm{CH}$ incidence greater in $\mathrm{T} 3$ than $\mathrm{T} 4$ group \\
\hline & T3 sympathicotomy, 85 patients underwent & \\
\hline & T4 sympathicotomy & \\
\hline \multirow[t]{5}{*}{ Abd Ellatif et $\mathrm{a}^{71}$} & Egypt & $\mathrm{CH}$ reported in $74.4 \%$ of $\mathrm{T} 3$ group \\
\hline & Palmar HH & $\mathrm{CH}$ reported in $28.3 \%$ of $\mathrm{T} 4$ group \\
\hline & 274 patients: 129 received T3 sympathectomy, & Higher incidence of mild to moderate $\mathrm{CH}$ in $\mathrm{T} 3$ group ( $64.4 \%$ vs $26.9 \%$; \\
\hline & I 45 received T4 sympathectomy & 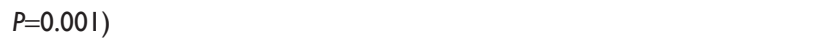 \\
\hline & Retrospective cohort study & Recurrence rate similar for T3 and T4 ( $0.8 \%$ vs I.4\%; $P=0.19)$ \\
\hline \multirow[t]{3}{*}{ Cerfolio et a $7^{72}$} & USA & Designation of disrupted level based on rib $(R)$ number ( $R \#$ rather \\
\hline & Expert consensus document & than $\mathrm{T \# )}$ \\
\hline & & Type of disruption should be explicitly noted (ablation vs resection, etc) \\
\hline
\end{tabular}

(Continued) 
Table I (Continued)

\begin{tabular}{|c|c|c|}
\hline Study & Description & Findings \\
\hline & & $\begin{array}{l}\text { Recommended levels for disruption of sympathetic chain based on } \mathrm{HH} \\
\text { type: } \\
\text { Palmar (isolated) HH: top of R3, top of R4 } \\
\text { Palmar, plantar, axillary HH: R4 and R5 } \\
\text { Craniofacial HH: top of R3 }\end{array}$ \\
\hline Miller and & USA & Median 4 days follow-up: $100 \%$ symptom resolution, $12 \%$ developed $\mathrm{CH}$ \\
\hline Force $^{73}$ & $\begin{array}{l}\text { Temporary sympathetic blockade } \\
\text { (with bupivacaine }+ \text { epinephrine) as predictor } \\
\text { of patients likely to develop } \mathrm{CH} \\
\text { Palmar, axillary, plantar } \mathrm{HH} \\
\text { I8 patients } \\
\text { Median } 4 \text { days }\end{array}$ & $\begin{array}{l}\text { (one of whom reported severe } \mathrm{CH} \text { and declined ETS) } \\
\text { Patients with mild } \mathrm{CH} \text { after temporary blockade also experienced mild } \\
\mathrm{CH} \text { after ETS } \\
\mathrm{I} 00 \% \text { of patients who underwent ETS were satisfied }\end{array}$ \\
\hline Zhu et $\mathrm{al}^{74}$ & $\begin{array}{l}\text { People's Republic of China } \\
\text { Transumbilical ETS vs traditional ETS } \\
\text { Palmar HH } \\
66 \text { patients ( } 34 \text { transumbilical, } 32 \text { traditional) }\end{array}$ & $\begin{array}{l}\text { I00\% of patients reported symptom resolution } \\
\text { Greater incidence of } \mathrm{CH} \text { in transumbilical group }(20.1 \%) \text { than in } \\
\text { traditional group }(18.8 \%) \text { - not statistically significant }(\mathrm{P}>0.05) \\
\text { Transumbilical approach associated with significantly fewer paresthesias } \\
\text { at I day, I month postoperatively }(P=0.015, P<0.00 \text { I, respectively) } \\
\text { Transumbilical approach achieved greater patient satisfaction with } \\
\text { cosmetic outcome }(94.1 \% \text { vs } 71.9 \% ; P=0.036)\end{array}$ \\
\hline Zhu et $\mathrm{al}^{75}$ & $\begin{array}{l}\text { People's Republic of China } \\
\text { Transumbilical ETS } \\
\text { Palmar and/or axillary HH } \\
35 \text { patients } \\
\text { I-year follow-up }\end{array}$ & $\begin{array}{l}\text { At I-year follow-up: } 97.1 \% \text { success in symptom resolution for palmar } \\
\mathrm{HH}, 72.2 \% \text { for axillary } \mathrm{HH} \\
94.3 \% \text { satisfied with the excellence in the cosmetic outcome of the } \\
\text { surgical incision }\end{array}$ \\
\hline $\begin{array}{l}\text { New therapies } \\
\text { Delivery of Btx }\end{array}$ & & \\
\hline Andrade et $\mathrm{al}^{76}$ & $\begin{array}{l}\text { Brazil } \\
\text { lontophoresis or phonophoresis for } \\
\text { percutaneous delivery of Btx A } \\
\text { Palmar } \mathrm{HH} \\
4 \text { patients }\end{array}$ & 16 weeks of symptom relief after 10 daily sessions \\
\hline $\begin{array}{l}\text { Vadoud-Seyedi } \\
\text { and Simonart }{ }^{77}\end{array}$ & $\begin{array}{l}\text { Belgium } \\
\text { Btx } \mathrm{A} \text { reconstituted in lidocaine vs Btx } \mathrm{A} \\
\text { reconstituted in saline } \\
\text { Axillary } \mathrm{HH} \\
29 \text { patients }\end{array}$ & $\begin{array}{l}\text { Symptom resolution in both groups } \\
\text { Significantly less pain with injection of lidocaine-reconstituted vs saline- } \\
\text { reconstituted preparation }(29.3 \pm 20 \text {.I vs } 47.5 \pm 24.0 ; P=0.0027)\end{array}$ \\
\hline Güleç $^{78}$ & $\begin{array}{l}\text { Turkey } \\
\text { Btx } \mathrm{A} \text { reconstituted in saline + lidocaine vs Btx } \mathrm{A} \\
\text { reconstituted in saline alone } \\
\text { Axillary } \mathrm{HH} \\
8 \text { patients } \\
\text { Pain (VAS) }\end{array}$ & $\begin{array}{l}\text { Symptom resolution in both groups } \\
\text { Significantly less pain in Btx A reconstituted with saline + lidocaine } \\
(41.3 \pm 15.3 \text { vs } 63.8 \pm 16.7 ; P=0.026)\end{array}$ \\
\hline Laser technology & & \\
\hline $\begin{array}{l}\text { Goldman and } \\
\text { Wollina }^{82}\end{array}$ & $\begin{array}{l}\text { Brazil } \\
\text { I,064 nm Nd:YAG laser (no control) } \\
\text { Axillary HH } \\
\text { I7 patients }\end{array}$ & $\begin{array}{l}\text { Histological analysis of laser-treated skin: microvesiculation, } \\
\text { decapitation, total vaporization of eccrine glands }\end{array}$ \\
\hline Letada et $\mathrm{al}^{85}$ & $\begin{array}{l}\text { USA } \\
\text { Long-pulsed I,064 nm Nd:YAG laser vs no } \\
\text { treatment of contralateral axillae } \\
\text { Axillary HH } \\
6 \text { patients }\end{array}$ & $\begin{array}{l}\text { Objective and subjective improvement in axillae treated by laser } \\
\text { compared with control (untreated axillae) } \rightarrow \text { only subjective changes } \\
\text { determined significant }(P<0.00 I) \\
\text { Histological evaluation: no differences between pre- and posttreatment }\end{array}$ \\
\hline Caplin and & USA & At I-year follow-up: $72 \%$ of patients reported 2 points improvement in \\
\hline Austin ${ }^{86}$ & $\begin{array}{l}\text { I,440 nm Nd:YAG laser (no control) } \\
\text { Axillary } \mathrm{HH} \\
\text { I5 patients } \\
\text { I-year follow-up }\end{array}$ & HDSS, $28 \%$ reported I point improvement in HDSS \\
\hline
\end{tabular}


Table I (Continued)

\begin{tabular}{|c|c|c|}
\hline Study & Description & Findings \\
\hline Bechara et $\mathrm{al}^{84}$ & $\begin{array}{l}\text { Germany } \\
\text { Long-pulsed } 800 \mathrm{~nm} \text { diode laser vs no } \\
\text { treatment contralateral axillae } \\
\text { Axillary } \mathrm{HH} \\
2 \mathrm{I} \text { patients }\end{array}$ & $\begin{array}{l}\text { No statistically significant difference between laser-treated and } \\
\text { untreated axillae } \\
\text { Both laser and control axillae demonstrated significant reduction in } \\
\text { sweat rates ( } P<0.001, P=0.04 \text {, respectively) } \\
\text { Histological evaluation: no significant changes between pre- and } \\
\text { posttreatment }\end{array}$ \\
\hline \multicolumn{3}{|c|}{ Microwave technology } \\
\hline Hong et $\mathrm{al}^{90}$ & $\begin{array}{l}\text { Canada } \\
\text { Microwave-based device (no control) } \\
\text { Axillary HH } \\
3 \text { I patients } \\
\text { HDSS, DLQI, gravimetric sweat measurements } \\
\text { Follow-up at I, 3, 6, I2 months }\end{array}$ & $\begin{array}{l}\text { Pretreatment: I00\% of patients reported HDSS of } 3 \text { or } 4 \\
\text { Percent of patients with } \geq 50 \% \downarrow \text { in gravimetric sweat measurements: at } \\
\text { I month: } 90 \% \text {, at } 3 \text { months: } 94 \% \text {, at } 6 \text { months: } 90 \% \text {, at I } 2 \text { months: } 90 \% \\
\text { At final }(I 2 \text {-month) visit: } \geq I \text { point } \downarrow \text { in HDSS in } 94 \% \text { of patients, } \\
\geq 2 \text { point } \downarrow \text { in HDSS in } 55 \% \text { of patients, average } \downarrow \text { in DLQI significantly } \\
>5 \text { points }(P<0.00 I) \\
\text { Adverse events: site-related redness, swelling, discomfort, abnormal } \\
\text { skin sensation, neuropathy, and weakness }\end{array}$ \\
\hline \multicolumn{3}{|c|}{ Ultrasound technology } \\
\hline Nestor and & USA & All patient pretreatment HDSS scores of 3 or 4 and $\geq 50 \mathrm{mg}$ per \\
\hline Park $^{93}$ & $\begin{array}{l}\text { MFU-V vs sham } \\
\text { Axillary HH } \\
\text { First study: I } 6 \text { patients total, I excluded due } \\
\text { to device malfunction, I lost to follow-up } \\
\text { Second study: } 20 \text { patients total, I lost to follow-up }\end{array}$ & $\begin{array}{l}\text { 5-minute period of axillary sweat secretion (per axillae) } \\
\text { First study: criteria for positive response: } \geq 50 \% \downarrow \text { spontaneous axillary } \\
\text { hidrosis on I } 20 \text { th day, }>50 \% \text { of patients positive response } \\
\text { Second study: criteria for positive response: } \downarrow \text { in HDSS from } 3 \text { or } 4 \text { to } \\
\text { I or } 2 \\
\text { Positive response in } 67 \% \text { of MFU-V group; no response in sham group } \\
(P<0.005) \\
\text { Statistically significant improvement in gravimetric measurement in } \\
\text { MFU-V group vs sham group ( } 83 \% \text { vs } 0 \%, P<0.000 \text { I) } \\
\text { Relationship between changes in HDSS and percent change in } \\
\text { gravimetric analysis }(P=0.005) \text { independent of time }\end{array}$ \\
\hline
\end{tabular}

Abbreviations: $\mathrm{HH}$, hyperhidrosis; Btx, botulinum toxin; Btx A, botulinum toxin A; Btx B, botulinum toxin B; DLQI, Dermatology Life Quality Index; CH, compensatory hyperhidrosis; LC, liposuction-curettage; SQ, subcutaneous; SC, skin conductance; VAS, visual analog scale; QOL, quality of life; ETS, endoscopic thoracic sympathectomy; MFU-V, microfocused ultrasound coupled with visualization; HDSS, Hyperhidrosis Disease Severity Scale; vs, versus.

last injections was recorded. The investigators showed that duration of efficacy of the injections increased with time in a statistically significant manner $(P<0.0002)$, where median duration of effect was 5.5 months for the first injection and 8.5 months for the last.

In a similar concurrent study of 28 patients, Lecouflet et $\mathrm{al}^{41}$ also showed increased duration of efficacy of Btx A injections with repetition in patients with primary palmar HH. Patients were treated with $250 \mathrm{U}$ of Btx A in each palm over approximately 11 years; injections were repeated when HH symptoms reemerged. The investigators demonstrated a statistically significant increase in longevity of the injections' effects with repetition, with median duration of effect of 7 months from initial injection to 9.5 months for the last $(P<0.0002) .{ }^{41}$ Interestingly, the results of this study undermine a common concern about chronic Btx injections: the risk of immunoresistance to the neurotoxin proteins. ${ }^{20}$ This evidence of increased duration of effect with repetition of injections serves to refute fears that resistance to the neurotoxin's effects may develop with repeated injections due to the formation of neutralizing antibodies. ${ }^{28,38,42}$ As elucidated in a study for such antibodies in Btx treatments for cervical dystonia, Jankovic et $\mathrm{al}^{43}$ explain that immunoresistance is more likely with high doses with each treatment, shorter periods between subsequent injections, and large cumulative dose. ${ }^{38}$ They also explain that a high protein content of the injection may be associated with greater risk of antibody formation. ${ }^{38,43}$

\section{Surgery Local excision}

Local excision of eccrine glands has been a treatment option for axillary $\mathrm{HH}$ for decades. ${ }^{44} 46$ The procedure, which is conducted on an outpatient basis with local anesthesia, ${ }^{47}$ can be performed either in combination with overlying skin excision (radical skin excision) or without skin removal (skin sparing). ${ }^{48}$ Proponents of radical skin excision consider this method to be more comprehensive because it involves removal of dermally located eccrine glands in addition to those located in the dermal-subcutaneous junction. ${ }^{47}$ 
Although effective in resolving symptoms, this procedure often requires the placement of drains ${ }^{49}$ and is associated with a number of complications and side effects, including infection, seroma, hematoma, necrosis, and atrophic or hypertrophic scarring. ${ }^{49-51}$ Since the introduction of glandular excision, advances in the local surgical treatment of axillary $\mathrm{HH}$ have included the addition of liposuction and/or curettage, with the goal of optimizing glandular disruption while minimizing surgical complications and offensive scars. ${ }^{14,49,51,52}$

\section{Liposuction-curettage}

Unlike excision of axillary skin and eccrine glands, LC is a minimally invasive and effective treatment for $\mathrm{HH}$ that results in improved cosmetic outcomes and less scarring. ${ }^{52}$ One retrospective trial performed in Germany highlights the advantages and disadvantages of both surgical procedures. In order to assess the differences in efficacy and risks of local skin excision with subcutaneous curettage versus tumescent LC, Wollina et al ${ }^{49}$ evaluated 162 patients with primary axillary HH. Thirty-seven patients underwent LC and the remaining 125 patients were treated by excision with subcutaneous curettage. Both objective (Minor's starch iodine test) and subjective (satisfaction scale) measures of effectiveness were employed. At 12 months postoperatively, the relapse rate for LC was $16.2 \%$ of patients and for excision with curettage was $1.0 \%$ of patients $(P<0.01) .{ }^{49}$ However, when asked about absence or near absence of pain in the acute period, patients who had undergone LC ( $89.2 \%$ pain free) fared significantly better than those who had received excision with curettage (24.0\% pain free; $P<0.01) .{ }^{49}$ A number of complications were seen in the excision group but not in the LC group: protracted healing time (14), wound infections (seven), and bleeding (two). ${ }^{49}$ Complications noted in the LC group were minor, including mild hematoma in 29 patients and sutureassociated irritation in six patients. ${ }^{49}$ Also noteworthy for the LC group was a significantly shorter time to return to work ( $1.3 \pm 0.8$ days vs $8.8 \pm 3.5$ days; $P<0.001)$ and surgical scars without atrophy, hypertrophy, or hyperpigmentation. ${ }^{49}$ Of note, patient to procedure allocation was not randomized, and while excision with curettage was reimbursed, patients who received LC were required to pay out of pocket for the procedure. Wollina et $\mathrm{al}^{49}$ concede that this may have influenced the LC group to anticipate better results from this more expensive treatment. Considering the less serious complications (and lower associated costs), better cosmetic outcome, and resolution of symptoms, LC provides a promising option for axillary $\mathrm{HH}^{49}$
In a study comparing isolated curettage versus LC for axillary $\mathrm{HH}$, Tronstad et $\mathrm{al}^{14}$ demonstrated significantly better symptom resolution with tumescent suction curettage. Each of the 22 patients received both treatments, LC to one axillae and isolated curettage to the opposite axillae. Data were available for only 17 of the 22 patients because of participant withdrawal or lack of follow-up. ${ }^{14}$ Evaluations were performed before surgery and at 3, 6, and 12 months postoperatively. Assessment for $\mathrm{HH}$, which was evaluated during stress testing, was performed objectively by SC and gravimetric measurement and subjectively by VAS. ${ }^{14}$ The LC group demonstrated significantly lower SC $(P=0.011)$ and gravimetric measurements $(P=0.028)$ as well as better VAS scores of sweating $(P<0.01)$ at all three postoperative visits. ${ }^{14}$ The authors suspect that because of the inherently more extensive tissue disruption associated with suctioning, LC is likely a more comprehensive procedure than is curettage alone, which simply disrupts glandular tissue without resecting it. ${ }^{14}$ Furthermore, because liposuction extracts adipose tissue, it is possible that mesenchymal stem cells within this tissue are also successfully removed with LC rather than left behind with simple curettage where they may have regenerative potential. ${ }^{14,53,54}$ Longer-term follow-up to elucidate the possible effects of retained mesenchymal stem cells on relapse of HH symptoms would be beneficial.

Ibrahim et $\mathrm{al}^{55}$ compared the effectiveness and patient satisfaction of LC versus Btx A injections in 20 axillary $\mathrm{HH}$ patients. Toxin injections were randomized to one axillae of each patient and the opposite axillae was treated by LC. Follow-up was performed at 3 and 6 months. No significant differences between the two treatment modalities were noted for baseline sweating levels at 3 months. However, for patients categorized as heavy sweaters, Btx injections provided significantly greater $\mathrm{HH}$ relief than did LC at 3 months $(P=0.0025)$. Furthermore, at both 3 and 6 months after treatment, patients reported greater satisfaction and improved QOL with Btx A injections ( 0.80 points; $P=0.0002)$ than with LC ( 0.90 points; $P=0.0017) .{ }^{55}$ Although the reason for differences in patient satisfaction with the two compared treatments is not elucidated, this study highlights the importance of offering more conservative treatment options before proceeding to surgical intervention for $\mathrm{HH}$.

\section{Sympathectomy}

In the interests of developing a safer procedure with optimized visualization of the sympathetic chain, $\mathrm{Kux}^{56}$ introduced a now commonly performed operation called ETS in 1951. Initially recommended in the treatment of peptic ulcer 
disease and other maladies, ${ }^{56}$ ETS has since been applied successfully to the treatment of primary $\mathrm{HH}$, particularly of the palms and soles. ${ }^{19,57}$ Although very effective in resolving symptoms of $\mathrm{HH}$, a significant concern with ETS is the development of $\mathrm{CH}$, a postsympathectomy condition of excessive sweating in a different anatomic region from the original $\mathrm{HH}$ manifestation..$^{58}$ Reported rates of $\mathrm{CH}$ after sympathectomy range from $30 \%$ to $90 \% .{ }^{59-61}$ Severe $\mathrm{CH}$ is defined as $\mathrm{CH}$ troublesome enough that the patient regrets undergoing ETS. ${ }^{57}$ The incidence of severe $\mathrm{CH}$ after sympathectomy is approximately $35 \% .{ }^{62} \mathrm{~A}$ discussion of this procedure's efficacy and incidence of $\mathrm{CH}$ follows.

In a retrospective cohort study of 210 patients with palmar, axillary, and/or craniofacial $\mathrm{HH}$, Bell et a ${ }^{63}$ evaluated the efficacy and incidence of adverse events with ETS as performed by a single surgeon. Electrocautery ablation was used on the sympathetic chain along its course over the second, third, and fourth ribs to target the second, third, and fourth thoracic ganglia; if identified intraoperatively, the accessory nerve(s) of Kuntz was also ablated. ${ }^{63}$ The median age of patients was 28 years, the youngest of whom was 11 years old. ETS for palmar and craniofacial $\mathrm{HH}$ yielded better resolution of $\mathrm{HH}$ than for axillary $\mathrm{HH}$, although all groups demonstrated statistically significant improvement: 97\% improvement in palmar, 93\% in craniofacial, and 71\% in axillary $\mathrm{HH}(P<0.001){ }^{63}$ Although $75 \%$ of patients developed $\mathrm{CH}$, only $12 \%$ considered it bothersome. The rates of severe $\mathrm{CH}$ were greatest in those treated for axillary $\mathrm{HH}(26 \%)$ and craniofacial $\mathrm{HH}(44.5 \%)$ and lowest in those treated for palmar $\mathrm{HH}(8 \% ; P=0.0003) .{ }^{63}$ Furthermore, while rates of severe $\mathrm{CH}$ increased with patient age, satisfaction with the results of ETS declined with age in a similar manner. ${ }^{63}$ Although ETS is an effective therapy for $\mathrm{HH}$, Bell et $\mathrm{a}^{63}$ emphasize the importance of transparent patient education about the risk of $\mathrm{CH}$ prior to surgery, as only $25 \%$ of patients who developed severe $\mathrm{CH}$ reported satisfaction with ETS even in light of improvement of their HH symptoms.

An alternative to sympathectomy, sympathotomy disrupts axons postsynaptically after the $\mathrm{T} 2$ ganglion to avoid overzealous neural injury that may result in the neuronal regeneration leading to severe $\mathrm{CH}^{57}$ In contrast with sympathectomy, sympathotomy does not include ganglionectomy. ${ }^{57}$ While the incidence of severe $\mathrm{CH}$ after sympathectomy is approximately $35 \%$, the rate of this adverse event after sympathotomy is approximately only $1.3 \%{ }^{62}$ In a study of 155 patients (44 male, 111 female) with palmar-plantar $\mathrm{HH}$, Atkinson et al ${ }^{57}$ evaluated the results from endoscopic thoracic limited sympathotomy, where the ganglion cells in T1 and T2 were undisturbed. Immediately postoperatively, all 155 study patients exhibited warm, dry palms and after more than 3 months postoperatively, 96.6\% demonstrated successful control of palmar hidrosis, $69.2 \%$ had diminished axillary sweating, and 39.8\% had decreased plantar sweating. Long-term follow-up revealed recurrence of palmar sweating in five patients, and severe $\mathrm{CH}$ was noted in only two patients $(1.3 \%))^{57}$

Heidemann and Licht $^{64}$ provide a comparison between thorascopic sympathicotomy and local axillary skin resection for the treatment of axillary HH in 96 patients. Median follow-up for determination of treatment efficacy was 26 months, performed by questionnaire by both groups (92\% of which were returned for inclusion in the study). Although recurrence of symptoms was more common with local skin excision ( $51 \%$ vs $5 \% ; P<0.001)$, this procedure was also associated with significantly better local symptom resolution $(P<0.001)$ and significantly less incidence of $\mathrm{CH}$ and gustatory sweating ( $25 \%$ vs $84 \%$ and $26 \%$ vs $54 \%$, respectively; $P=0.01){ }^{64}$

Some studies suggest that limiting the levels obliterated during ETS may result in lower risk of $\mathrm{CH},{ }^{57,65-67}$ while others refute this claim. ${ }^{58,68,69}$ Lesèche et al ${ }^{69}$ evaluated 134 patients with either isolated palmar or axillary $\mathrm{HH}$ or a combination of the two to determine the relationship between extent of sympathectomy and occurrence of $\mathrm{CH}$. Although sympathectomies can range from level $\mathrm{T} 1$ to $\mathrm{T} 5$, a recent prospective study revealed no significant difference in incidence and severity of $\mathrm{CH}$ with respect to degree of sympathectomy. ${ }^{69}$ The authors concede that low statistical power may have contributed to limitations of this study's interpretability. ${ }^{69}$

In contrast, Yuncu et a ${ }^{66}$ demonstrated significantly lower $\mathrm{CH}$ incidence after limited sympathectomy (T3 only) compared with sympathectomy of T3 and T4. Sixty patients with axillary $\mathrm{HH}$ were randomized to either group 1 or group 2. The 17 patients in group 1 received sympathectomy of $\mathrm{T} 3$ and $\mathrm{T} 4$, while the 43 patients in group 2 underwent only $\mathrm{T} 3$ sympathectomy. All 60 patients experienced immediate and lasting (1 year) resolution of their axillary HH. However, at 1-year follow-up, group 1 demonstrated significantly more $\mathrm{CH}$ than did group $2(100 \%$ vs $79 \% ; P=0.008) .{ }^{66}$

Although degree of sympathotomy/sympathectomy (total number of levels disrupted) has not been conclusively correlated with risk of $\mathrm{CH}$, it appears that the absolute level has, with lower chain disruption resulting in lower $\mathrm{CH}$ incidence. ${ }^{70,71}$ In their assessment of T3 versus T4 sympathicotomy for palmar $\mathrm{HH}$ in 163 patients, Yang et $\mathrm{al}^{70}$ found a significantly lower rate of moderate $\mathrm{CH}$ in the $\mathrm{T} 4$ group. 
(No significant difference between the two groups was observed in rates of mild $\mathrm{HH}$ ). Similarly, a retrospective review by Abd Ellatif et al $^{71}$ in Egypt also revealed a greater incidence of $\mathrm{CH}$ following $\mathrm{T} 3$ versus T4 sympathectomy for palmar HH. From the total of 274 patients, 129 had T3 disruption, whereas 145 had T4 disruption of the sympathetic chain. While $74.4 \%$ of the T3 group reported $\mathrm{CH}$, only $28.3 \%$ of the T4 group reported this adverse effect. ${ }^{71}$

The variability in type and extent of sympathetic chain disruption has presented significant challenges in drawing useful comparisons of the various procedures performed in different centers throughout the world. A consensus article from Cerfolio et $\mathrm{al}^{72}$ recommends a standardized nomenclature for sympathetic chain disruption and provides sympathectomy guidelines for practitioners based on $\mathrm{HH}$ type. The consensus authors recognized that the lack of a standardized naming convention impeded interpretation and comparison of procedures performed by different surgeons. Furthermore, considering the variability in anatomy between patients, the authors noted that nomenclature based on more consistent anatomic landmarks was warranted. Therefore, the authors recommended the designation " $\mathrm{R}$ " for rib followed by the rib number to denote the location of chain disruption. In addition, the method of interruption should be explicitly stated (eg, cauterized, clipped, cut). ${ }^{72}$ In regard to the optimal levels of chain disruption based on type of $\mathrm{HH}$, Cerfolio et $\mathrm{al}^{72}$ recommend chain disruption at the top of R3 or R4 for isolated palmar HH; R4 and R5 for palmar, plantar, and axillary $\mathrm{HH}$; and the top of $\mathrm{R} 3$ for craniofacial $\mathrm{HH}$.

Miller and Force ${ }^{73}$ presented the option of performing a temporary sympathetic blockade before definitive sympathectomy to predict those patients most likely to develop $\mathrm{CH}$ and therefore be dissatisfied with the results of ETS. In their assessment of 18 patients suffering from combinations of palmar, axillary, and plantar $\mathrm{HH}$, the operators performed temporary blockades of T2, T3, and accessory nerves with bupivacaine plus epinephrine. For a median of 4 days, all patients experienced relief of $\mathrm{HH}$ and three of the $18(12 \%)$ developed $\mathrm{CH}^{73}$ Only one of these patients reported severe $\mathrm{CH}$ and decided not to proceed with ETS. Interestingly, the two patients who endorsed mild $\mathrm{CH}$ symptoms after temporary blockade were the same two participants who experienced mild $\mathrm{CH}$ after ETS. Nevertheless, all patients who underwent ETS were satisfied with the results of the procedure. ${ }^{73}$ The authors suggest that temporary sympathetic blockade at the anticipated surgical levels be performed to help predict likelihood of developing $\mathrm{CH}$ after ETS. ${ }^{73}$
Beyond the risk of $\mathrm{CH}$ following ETS, there is also concern about cosmetic outcome and risk of chronic chest wall pain and paresthesias. ${ }^{74,75}$ Although the thoracic wall approach with endoscopy involves the creation of relatively small incisions, ${ }^{75}$ the desire for a less invasive approach and interest in preventing intercostal nerve injury have driven new procedural innovations. Investigators in the People's Republic of China have recently explored the possibility of using natural orifice access for thoracic sympathectomy in the treatment of $\mathrm{HH}$ and have shown promising preliminary results. Zhu et $\mathrm{al}^{74}$ evaluated 66 patients with palmar $\mathrm{HH}$, 34 of whom underwent transumbilical ETS and 32 of whom underwent traditional transthoracic VATS. All 66 patients reported successful treatment of their palmar HH. Although $\mathrm{CH}$ was noted in more transumbilical patients (seven patients, $20.1 \%$ ) than in VATS patients (six patients, 18.8\%), the difference was not statistically significant $(P>0.05) .{ }^{74}$ Patients who had received transumbilical ETS reported significantly fewer paresthesias at 1 day, 1 week, and 1 month after surgery compared with those who underwent VATS $(P=0.015$, $P<0.001, P<0.001$, respectively). In further support of the transumbilical approach, patients who had received this intervention reported significantly greater satisfaction with cosmetic outcome as well $(94.1 \%$ vs $71.9 \% ; P=0.036) .{ }^{74}$ In a subsequent study by Zhu et al, ${ }^{75}$ a 1 -year follow-up was provided for 35 patients who had received transumbilical thoracic sympathectomy for palmar and/or axillary HH. At 1 year, a $97.1 \%$ success rate (34 of 35) for palmar $\mathrm{HH}$ was noted, and a $72.2 \%$ success rate (13 of 18 ) was reported for axillary $\mathrm{HH} .{ }^{75}$ Out of all 35 patients, $94.3 \%$ reported satisfaction with cosmetic outcome of the $5 \mathrm{~mm}$ incision transumbilical approach at 12 months postoperatively. ${ }^{75} \mathrm{~A}$ transumbilical approach for sympathectomy may be associated with fewer postoperative complications, lower risk of chest wall pain and paresthesias, and better cosmetic outcomes. ${ }^{74,75}$

\section{New and emerging therapies New delivery methods for Btx}

An intriguing investigation by Andrade et $\mathrm{al}^{76}$ evaluated the use of iontophoresis or phonophoresis to facilitate delivery of Btx A percutaneously for palmar HH. They evaluated four patients after ten daily sessions of either phonophoresis- or iontophoresis-mediated Btx administration. Improvement of $\mathrm{HH}$ lasted for 16 weeks after treatment. ${ }^{76}$ Because iontophoresis alone is a treatment available for $\mathrm{HH}$, it would have been useful to see a comparison of this combination therapy (iontophoresis or phonophoresis plus Btx A) versus each individual treatment alone. Considering this weakness of the 
study, it is impossible to interpret the relative contributions to therapeutic effect of the individual components of this treatment regimen. Although this study represents a preliminary small sample view of this combination of $\mathrm{HH}$ therapies, it may be a promising option for patients for whom needle injections for Btx administration are unacceptable.

In the interests of exploring less painful options for $\mathrm{HH}$ patients interested in Btx injections, Vadoud-Seyedi and Simonart ${ }^{77}$ performed a double-blind, randomized trial where one axillae of each patient was treated with Btx A reconstituted in lidocaine, and the contralateral axillae treated with Btx A reconstituted in saline (equal volumes). A total of 29 patients were evaluated and follow-up was provided for up to 8 months. Although both lidocaine- and saline-reconstituted Btx A successfully treated $\mathrm{HH}$, the lidocaine-Btx A combination was associated with significantly less pain than the saline-Btx A solution during the injection (29.3 \pm 20.1 vs 47.5 $\pm 24.0 ; P=0.0027)$.

Güleç $^{78}$ performed a similar assessment of relative pain differences with Btx A injections when lidocaine is added to saline. Each of the eight participants received both treatment combinations - one type for each axillae in a randomized manner. While one axillae was injected with $50 \mathrm{U}$ Btx A combined with $0.5 \mathrm{~mL}$ saline and $1.0 \mathrm{~mL}$ of $2 \%$ lidocaine, the contralateral axillae received $50 \mathrm{U}$ Btx A with $1.5 \mathrm{~mL}$ saline only. Successful resolution of axillary $\mathrm{HH}$ was seen in both treatment combinations (without significant differences in efficacy between the two), but pain by VAS was significantly less in the Btx A-lidocaine-treated axilla than the Btx A-salinetreated axilla $(41.3 \pm 15.3$ vs $63.8 \pm 16.7 ; P=0.026){ }^{78}$

\section{Laser technology}

Beyond serving as a modality during sympathectomy for $\mathrm{HH},{ }^{79,80}$ laser technology has also been employed externally for glandular disruption in the treatment of $\mathrm{HH}$ and osmidrosis. ${ }^{81-87}$ Goldman and Wollina ${ }^{82}$ investigated the use of a 1,064 nm Nd:YAG laser for axillary $\mathrm{HH}$ in 17 patients and determined this modality safe and effective by subjective and objective measures ( $P$-value not provided). Histological analysis of laser-treated axillary skin revealed microvesiculation and decapitation to total vaporization of eccrine glands, findings to which they attributed the clinical effects of laser treatment. ${ }^{82}$ Of note, pretreatment tissue samples were not obtained and histologically evaluated.

In their prospective, case-controlled, randomized evaluation, Letada et al $^{85}$ similarly evaluated the long-pulsed 1,064 nm Nd:YAG laser in the treatment of axillary $\mathrm{HH}$ in six patients. One axillae of each patient received $\mathrm{Nd}$ :YAG laser treatment monthly, while the opposite axillae of each patient served as a control. Tissue samples for histological evaluation were obtained before and after laser treatment. Both objective (starch iodine test) and subjective improvements were noted in comparison with the contralateral untreated axillae, although only subjective changes were determined statistically significant $(P<0.001)$. Histological evaluation demonstrated no differences between pre- and posttreatment histologic specimens. ${ }^{85}$

Caplin and Austin ${ }^{86}$ also demonstrated durability of laser treatment for axillary $\mathrm{HH}$ in their study of 15 patients treated with a 1,440 nm Nd:YAG laser. At 1 year posttreatment, improvement in HDSS of two points was seen in $72 \%$ of patients, while improvement of one point was seen in $28 \%$ of patients.

Bechara et al $^{84}$ evaluated the use of a long-pulsed $800 \mathrm{~nm}$ diode laser for axillary $\mathrm{HH}$ in a randomized, controlled study of 21 patients. The contralateral axillae of each patient served as a control while the treated side received five cycles of the $800 \mathrm{~nm}$ diode laser. In contrast with the studies described earlier, no statistically significant difference was observed between the treated and nontreated sides. However, both the laser-treated and non-treated sides did demonstrate reduction in sweat rates that was statistically significant $(P<0.001$, $P=0.04$, respectively).$^{84}$ Comparison of histological evaluation before and after treatment revealed no significant changes in eccrine nor apocrine gland apparatuses, including glandular damage and changes in gland size or number. ${ }^{84}$

While some investigators have found lasers useful in the treatment of $\mathrm{HH}$, others have serendipitously observed the development of excessive sweating after laser hair removal in the axillary ${ }^{74}$ and inguinal regions. ${ }^{88,89}$ Although more studies are necessary, laser treatment for $\mathrm{HH}$ may provide a promising option for patients who have received unsatisfactory results from topical and/or systemic treatments and are interested in exploring other relatively less invasive modalities before considering surgery.

\section{Microwave technology}

Hong et $\mathrm{al}^{90}$ evaluated a recently US Food and Drug Administration (FDA)-approved microwave-based device designed by Miramar Labs for its efficacy in treating axillary $\mathrm{HH}$ in 31 patients. The microwave's selective heating of the dermis and glandular tissue more than subcutaneous fat is based on the relatively greater water content. ${ }^{91}$ Because apocrine glands are also located in the target region, the study was able to evaluate the microwave technology's effects on axillary bromhidrosis as well. ${ }^{90}$ Assessments were performed with HDSS, DLQI, and gravimetric sweat 
measurements; all patients reported a pretreatment HDSS of either 3 or 4 . After completion of the procedures, follow-up was performed at $1,3,6$, and 12 months. The investigators found that $94 \%$ of patients experienced at least a one-point decrease in HDSS, while 55\% reported a two-point or greater drop in HDSS. ${ }^{90}$ Furthermore, the average reduction in DLQI (over the follow-up intervals) was significantly greater than five points $(P<0.001) .{ }^{90}$ Gravimetric sweat measurements also improved after microwave therapy, with a $\geq 50 \%$ reduction in $90 \%, 94 \%, 90 \%$, and $90 \%$ of patients at $1,3,6$, and 12 months, respectively. ${ }^{90}$ Patients with pretreatment axillary bromhidrosis also reported statistically significant decreases in axillary odor with treatment $(P<0.001) .{ }^{90}$ Adverse transient events associated with this treatment included site-related redness, swelling, and discomfort, while a longer-lasting side effect was abnormal skin sensation. One patient reported arm neuropathy and weakness on the treated side that improved after 6 months..$^{90}$ In a separate investigation, Suh et $\mathrm{al}^{92}$ describe a case of median and ulnar neuropathy after microwave device treatment for axillary $\mathrm{HH}$ that resolved after 12 months.

\section{Ultrasound technology}

Employing another method to selectively target glandular tissue in the treatment of hyper $\mathrm{HH}$ hidrosis, Nestor and Park $^{93}$ examined the use of a device that had been FDA approved for noninvasive eyebrow and neck lifts in two prospective randomized, double-blind, sham-controlled studies. Using high-intensity microfocused ultrasound coupled with visualization (MFU-V), the practitioner creates small thermal injuries within the dermis. Visualization allows the operator to ensure localization at the desired treatment region and avoidance of sensitive anatomic structures such as large blood vessels. ${ }^{93}$ (For a more extensive discussion on the technology, we refer the reader to White et al's ${ }^{94}$ original investigation using cadaveric tissue). Inclusion criteria for the studies required $\geq 50 \mathrm{mg}$ per 5-minute period of axillary sweat secretion (per axillae) and an HDSS score of 3 or 4 . In the first study, gravimetric measurements were obtained to evaluate for objective improvement, where at least a $50 \%$ decrease in spontaneous axillary hidrosis measured on the 120 th day was considered a positive response. The evaluators report that more than half of the patients in the first study demonstrated a positive response. ${ }^{93}$ The second study evaluated both subjective improvement of $\mathrm{HH}$ where a drop in HDSS scores from 3 or 4 to 1 or 2 was considered a positive response, as well as objective improvement as determined by gravimetric measurement. For this study, $67 \%$ of patients in the MFU-V group demonstrated a positive response according to the HDSS parameters, whereas none demonstrated response in the sham group $(P<0.005) .{ }^{93}$ Compared with the sham group, the MFU-V group also demonstrated statistically significant improvement according to gravimetric measurement ( $83 \%$ vs $0 \%, P<0.0001) .{ }^{93}$ Nestor and Park $^{93}$ also observed a significant relationship between changes in HDSS and percent change in gravimetric analysis $(P=0.005)$ that was independent of time.

\section{Conclusion}

A wide array of therapies are available for the treatment of primary $\mathrm{HH}$, ranging from topical to systemic medications, intradermal injections, to minimally versus fully invasive surgery. Some therapies carry significantly greater risks of adverse events than others. Often, the patient and physician are required to explore the options by trial and error. While the efficacy of oxybutynin systemic therapy has been demonstrated in multiple studies, ${ }^{21-26}$ patients may find the anticholinergic side effects unacceptable. ${ }^{21,26}$ Btx injections are effective and should be considered in those patients who have failed topical and systemic therapies. 1,11,20,27,29,35-38,40,41 New forms of administration of Btx may make this option more palatable for patients weary of injections, ${ }^{76-78}$ especially for those seeking treatment for axillary HH. LC successfully relieves $\mathrm{HH}$ and, by virtue of the suctioning mechanism, may be superior to curettage alone for lasting results. ${ }^{14,49,52}$ Sympathotomy and sympathectomy are the most invasive procedures for $\mathrm{HH}$, but for those patients whose daily lives are disrupted by $\mathrm{HH}$, despite trials of other therapeutic options, sympathetic chain disruption may present an appealing opportunity for treatment. ${ }^{19,57,63,70-73}$ Certainly, the risk of $\mathrm{CH}$ should be discussed thoroughly with patients considering this intervention. ${ }^{58,62,63}$ In order to limit the risk of $\mathrm{CH}$ and chest wall pain, paresthesias, and scars, ${ }^{74,75}$ experimentation with altering the techniques and levels disrupted during sympathotomy/sympathectomy continues. ${ }^{57,58,65-72}$ Preliminary investigations of new technologies (laser, microwave, and ultrasound) for less invasive eccrine gland disruption are promising. ${ }^{82,84-86,90-94}$ Ultimately, the determination of which modality to pursue should be individualized to each particular patient, carefully considering the effects of $\mathrm{HH}$ on QOL while weighing the potential benefits and adverse events of the proposed treatment.

\section{Disclosure}

The authors report no conflicts of interest in this work. 


\section{References}

1. Naumann M, Lowe NJ, Kumar CR, Hamm H, Group HCI. Botulinum toxin type a is a safe and effective treatment for axillary hyperhidrosis over 16 months: a prospective study. Arch Dermatol. 2003;139(6): 731-736.

2. Ram R, Lowe NJ, Yamauchi PS. Current and emerging therapeutic modalities for hyperhidrosis, part 1: conservative and noninvasive treatments. Cutis. 2007;79(3):211-217.

3. Strutton DR, Kowalski JW, Glaser DA, Stang PE. US prevalence of hyperhidrosis and impact on individuals with axillary hyperhidrosis: results from a national survey. J Am Acad Dermatol. 2004;51(2): 241-248.

4. Slingluff CL, Petroni GR, Molhoek KR, et al. Clinical activity and safety of combination therapy with temsirolimus and bevacizumab for advanced melanoma: a phase II trial (CTEP 7190/Mel47). Clin Cancer Res. 2013;19(13):3611-3620.

5. Hornberger J, Grimes K, Naumann M, et al. Recognition, diagnosis, and treatment of primary focal hyperhidrosis. J Am Acad Dermatol. 2004;51(2):274-286.

6. Cetindag IB, Boley TM, Webb KN, Hazelrigg SR. Long-term results and quality-of-life measures in the management of hyperhidrosis. Thorac Surg Clin. 2008;18(2):217-222.

7. Ro KM, Cantor RM, Lange KL, Ahn SS. Palmar hyperhidrosis: evidence of genetic transmission. J Vasc Surg. 2002;35(2):382-386.

8. Haider A, Solish N. Focal hyperhidrosis: diagnosis and management. CMAJ. 2005;172(1):69-75.

9. Groscurth P. Anatomy of sweat glands. Curr Probl Dermatol. 2002;30:1-9.

10. Eisenach JH, Atkinson JL, Fealey RD. Hyperhidrosis: evolving therapies for a well-established phenomenon. Mayo Clin Proc. 2005;80(5):657-666.

11. Solish N, Benohanian A, Kowalski JW, Hyperhidrosis CDSGoH-RQoLiPA. Prospective open-label study of botulinum toxin type A in patients with axillary hyperhidrosis: effects on functional impairment and quality of life. Dermatol Surg. 2005;31(4):405-413.

12. Vetrugno R, Liguori R, Cortelli P, Montagna P. Sympathetic skin response: basic mechanisms and clinical applications. Clin Auton Res. 2003;13(4):256-270.

13. Manca D, Valls-Solé J, Callejas MA. Excitability recovery curve of the sympathetic skin response in healthy volunteers and patients with palmar hyperhidrosis. Clin Neurophysiol. 2000;111(10): 1767-1770.

14. Tronstad C, Helsing P, Tønseth KA, Grimnes S, Krogstad AL. Tumescent suction curettage vs curettage only for treatment of axillary hyperhidrosis evaluated by subjective and new objective methods. Acta Derm Venereol. 2014;94(2):215-220.

15. de Moura Júnior NB, das-Neves-Pereira JC, de Oliveira FR, et al. Expression of acetylcholine and its receptor in human sympathetic ganglia in primary hyperhidrosis. Ann Thorac Surg. 2013;95(2): $465-470$

16. Low PA, Caskey PE, Tuck RR, Fealey RD, Dyck PJ. Quantitative sudomotor axon reflex test in normal and neuropathic subjects. Ann Neurol. 1983;14(5):573-580.

17. Braune C, Erbguth F, Birklein F. Dose thresholds and duration of the local anhidrotic effect of botulinum toxin injections: measured by sudometry. Br J Dermatol. 2001;144(1):111-117.

18. Solish N, Bertucci V, Dansereau A, et al. A comprehensive approach to the recognition, diagnosis, and severity-based treatment of focal hyperhidrosis: recommendations of the Canadian Hyperhidrosis Advisory Committee. Dermatol Surg. 2007;33(8):908-923.

19. Kuijpers M, Klinkenberg TJ, Bouma W, DeJongste MJ, Mariani MA. Single-port one-stage bilateral thoracoscopic sympathicotomy for severe hyperhidrosis: prospective analysis of a standardized approach. J Cardiothorac Surg. 2013;8:216.

20. Rosell K, Hymnelius K, Swartling C. Botulinum toxin type A and $\mathrm{B}$ improve quality of life in patients with axillary and palmar hyperhidrosis. Acta Derm Venereol. 2013;93(3):335-339.
21. Wolosker N, Teivelis MP, Krutman M, et al. Long-term results of the use of oxybutynin for the treatment of axillary hyperhidrosis. Ann Vasc Surg. 2014;28(5):1106-1112.

22. Wolosker N, de Campos JR, Kauffman P, Puech-Leão P. A randomized placebo-controlled trial of oxybutynin for the initial treatment of palmar and axillary hyperhidrosis. J Vasc Surg. 2012;55(6):1696-1700.

23. Wolosker N, Krutman M, Teivelis MP, et al. Analysis of oxybutynin treatment for hyperhidrosis in patients aged over 40 years. Einstein (Sao Paulo). 2014;12(1):42-47.

24. Wolosker N, de Campos JR, Kauffman P, et al. An alternative to treat palmar hyperhidrosis: use of oxybutynin. Clin Auton Res. 2011;21(6):389-393.

25. Mijnhout GS, Kloosterman H, Simsek S, Strack van Schijndel RJ, Netelenbos JC. Oxybutynin: dry days for patients with hyperhidrosis. Neth J Med. 2006;64(9):326-328.

26. Tupker RA, Harmsze AM, Deneer VH. Oxybutynin therapy for generalized hyperhidrosis. Arch Dermatol. 2006;142(8):1065-1066.

27. Birklein F, Eisenbarth G, Erbguth F, Winterholler M. Botulinum toxin type B blocks sudomotor function effectively: a 6 month follow-up. J Invest Dermatol. 2003;121(6):1312-1316.

28. Jankovic J, Schwartz KS. Longitudinal experience with botulinum toxin injections for treatment of blepharospasm and cervical dystonia. Neurology. 1993;43(4):834-836.

29. Heckmann M, Ceballos-Baumann AO, Plewig G, Group HS. Botulinum toxin A for axillary hyperhidrosis (excessive sweating). $N$ Engl J Med. 2001;344(7):488-493.

30. Heckmann M, Schaller M, Ceballos-Baumann A, Plewig G. Botulinum beyond wrinkles. Dermatol Surg. 1997;23(12):1221-1222.

31. Lew MF, Brashear A, Factor S. The safety and efficacy of botulinum toxin type $B$ in the treatment of patients with cervical dystonia: summary of three controlled clinical trials. Neurology. 2000;55(12 Suppl 5):S29-S35.

32. Frevert J. Xeomin: an innovative new botulinum toxin type A. Eur $J$ Neurol. 2009;16 Suppl 2:11-13.

33. Wollina U. Botulinum toxin: non-cosmetic indications and possible mechanisms of action. J Cutan Aesthet Surg. 2008;1(1):3-6.

34. Kreyden OP, Scheidegger EP. Anatomy of the sweat glands, pharmacology of botulinum toxin, and distinctive syndromes associated with hyperhidrosis. Clin Dermatol. 2004;22(1):40-44.

35. Bushara KO, Park DM. Botulinum toxin and sweating. J Neurol Neurosurg Psychiatry. 1994;57(11):1437-1438.

36. Bushara KO, Park DM, Jones JC, Schutta HS. Botulinum toxin a possible new treatment for axillary hyperhidrosis. Clin Exp Dermatol. 1996;21(4):276-278.

37. Basciani M, Di Rienzo F, Bizzarrini M, Zanchi M, Copetti M, Intiso D. Efficacy of botulinum toxin type B for the treatment of primary palmar hyperhidrosis: a prospective, open, single-blind, multi-centre study. Arch Dermatol Res. 2014;306(5):497-503.

38. Lecouflet M, Leux C, Fenot M, Célerier P, Maillard H. Duration of efficacy increases with the repetition of botulinum toxin A injections in primary axillary hyperhidrosis: a study in 83 patients. $J$ Am Acad Dermatol. 2013;69(6):960-964.

39. Lecouflet M, Leux C, Fenot M, Célerier P, Maillard H. Duration of efficacy increases with the repetition of botulinum toxin A injections in primary palmar hyperhidrosis: a study of 28 patients. $J$ Am Acad Dermatol. 2014;70(6):1083-1087.

40. Naumann M, Lowe NJ. Botulinum toxin type A in treatment of bilateral primary axillary hyperhidrosis: randomised, parallel group, double blind, placebo controlled trial. BMJ. 2001;323(7313):596-599.

41. Lecouflet M, Leux C, Fenot M, Célerier P, Maillard H. Duration of efficacy increases with the repetition of botulinum toxin A injections in primary palmar hyperhidrosis: a study of 28 patients. $J$ Am Acad Dermatol. 2014;70(6):1083-1087.

42. Thant ZS, Tan EK. Emerging therapeutic applications of botulinum toxin. Med Sci Monit. 2003;9(2):RA40-RA48.

43. Jankovic J, Vuong KD, Ahsan J. Comparison of efficacy and immunogenicity of original versus current botulinum toxin in cervical dystonia. Neurology. 2003;60(7):1186-1188. 
44. Munro DD, Verbov JL, O’Gorman DJ, du Vivier A. Axillary hyperhidrosis. Its quantification and surgical treatment. Br J Dermatol. 1974;90(3):325-329.

45. Bergkvist L, Engevik L. The surgical treatment of axillary hyperhidrosis. Br J Surg. 1979;66(7):482-484.

46. Bretteville-Jensen G, Mossing N, Albrechtsen R. Surgical treatment of axillary hyperhidrosis in 123 patients. Acta Derm Venereol. 1975;55(1):73-77.

47. Hafner J, Beer GM. Axillary sweat gland excision. Curr Probl Dermatol. 2002;30:57-63.

48. Bechara FG, Sand M, Hoffmann K, Boorboor P, Altmeyer P, Stuecker M. Histological and clinical findings in different surgical strategies for focal axillary hyperhidrosis. Dermatol Surg. 2008;34(8):1001-1009; discussion 1009.

49. Wollina U, Köstler E, Schönlebe J, Haroske G. Tumescent suction curettage versus minimal skin resection with subcutaneous curettage of sweat glands in axillary hyperhidrosis. Dermatol Surg. 2008;34(5):709-716.

50. Connolly M, de Berker D. Management of primary hyperhidrosis: a summary of the different treatment modalities. Am J Clin Dermatol. 2003;4(10):681-697.

51. Schlereth T, Dieterich M, Birklein F. Hyperhidrosis - causes and treatment of enhanced sweating. Dtsch Arztebl Int. 2009;106(3):32-37.

52. Bechara FG, Sand M, Tomi NS, Altmeyer P, Hoffmann K. Repeat liposuction-curettage treatment of axillary hyperhidrosis is safe and effective. Br J Dermatol. 2007;157(4):739-743.

53. Kingham PJ, Kalbermatten DF, Mahay D, Armstrong SJ, Wiberg M, Terenghi G. Adipose-derived stem cells differentiate into a Schwann cell phenotype and promote neurite outgrowth in vitro. Exp Neurol. 2007;207(2):267-274.

54. Hilfiker A, Kasper C, Hass R, Haverich A. Mesenchymal stem cells and progenitor cells in connective tissue engineering and regenerative medicine: is there a future for transplantation? Langenbecks Arch Surg. 2011;396(4):489-497.

55. Ibrahim O, Kakar R, Bolotin D, et al. The comparative effectiveness of suction-curettage and onabotulinumtoxin-A injections for the treatment of primary focal axillary hyperhidrosis: a randomized control trial. J Am Acad Dermatol. 2013;69(1):88-95.

56. Kux E. The endoscopic approach to the vegetative nervous system and its therapeutic possibilities; especially in duodenal ulcer, angina pectoris, hypertension and diabetes. Dis Chest. 1951;20(2):139-147.

57. Atkinson JL, Fode-Thomas NC, Fealey RD, Eisenach JH, Goerss SJ. Endoscopic transthoracic limited sympathotomy for palmar-plantar hyperhidrosis: outcomes and complications during a 10-year period. Mayo Clin Proc. 2011;86(8):721-729.

58. Ibrahim M, Menna C, Andreetti C, et al. Two-stage unilateral versus one-stage bilateral single-port sympathectomy for palmar and axillary hyperhidrosis. Interact Cardiovasc Thorac Surg. 2013;16(6):834-838.

59. Askari A, Kordzadeh A, Lee GH, Harvey M. Endoscopic thoracic sympathectomy for primary hyperhidrosis: a 16-year follow-up in a single UK centre. Surgeon. 2013;11(3):130-133.

60. Ojimba TA, Cameron AE. Drawbacks of endoscopic thoracic sympathectomy. Br J Surg. 2004;91(3):264-269.

61. Licht PB, Jørgensen OD, Ladegaard L, Pilegaard HK. Thoracoscopic sympathectomy for axillary hyperhidrosis: the influence of T4. Ann Thorac Surg. 2005;80(2):455-459; discussion 459-460.

62. Adefusika JA, Brewer JD. OnabotulinumtoxinA therapy for compensatory hyperhidrosis. J Cosmet Dermatol. 2013;12(3):232-234.

63. Bell D, Jedynak J, Bell R. Predictors of outcome following endoscopic thoracic sympathectomy. ANZ J Surg. 2014;84(1-2):68-72.

64. Heidemann E, Licht PB. A comparative study of thoracoscopic sympathicotomy versus local surgical treatment for axillary hyperhidrosis. Ann Thorac Surg. 2013;95(1):264-268.

65. Hederman WP. Present and future trends in thoracoscopic sympathectomy. Eur J Surg Suppl. 1994;(572):17-19.

66. Yuncu G, Turk F, Ozturk G, Atinkaya C. Comparison of only T3 and T3-T4 sympathectomy for axillary hyperhidrosis regarding treatment effect and compensatory sweating. Interact Cardiovasc Thorac Surg. 2013;17(2):263-267.
67. Aoki H, Sakai T, Murata H, Sumikawa K. Extent of sympathectomy affects postoperative compensatory sweating and satisfaction in patients with palmar hyperhidrosis. J Anesth. 2014;28(2):210-213.

68. Lai YT, Yang LH, Chio CC, Chen HH. Complications in patients with palmar hyperhidrosis treated with transthoracic endoscopic sympathectomy. Neurosurgery. 1997;41(1):110-113; discussion 113-115.

69. Lesèche G, Castier Y, Thabut G, et al. Endoscopic transthoracic sympathectomy for upper limb hyperhidrosis: limited sympathectomy does not reduce postoperative compensatory sweating. J Vasc Surg. 2003;37(1):124-128.

70. Yang J, Tan JJ, Ye GL, Gu WQ, Wang J, Liu YG. T3/T4 thoracic sympathictomy and compensatory sweating in treatment of palmar hyperhidrosis. Chin Med J (Engl). 2007;120(18):1574-1577.

71. Abd Ellatif ME, Hadidi AE, Musa AM, et al. Optimal level of sympathectomy for primary palmar hyperhidrosis: T3 versus T4 in a retrospective cohort study. Int J Surg. 2014;12(8):778-782.

72. Cerfolio RJ, De Campos JR, Bryant AS, et al. The Society of Thoracic Surgeons expert consensus for the surgical treatment of hyperhidrosis. Ann Thorac Surg. 2011;91(5):1642-1648.

73. Miller DL, Force SD. Temporary thoracoscopic sympathetic block for hyperhidrosis. Ann Thorac Surg. 2008;85(4):1211-1214; discussion 1215-1216.

74. Zhu LH, Chen L, Yang S, et al. Embryonic NOTES thoracic sympathectomy for palmar hyperhidrosis: results of a novel technique and comparison with the conventional VATS procedure. Surg Endosc. 2013;27(11):4124-4129.

75. Zhu LH, Du Q, Chen L, et al. One-year follow-up period after transumbilical thoracic sympathectomy for hyperhidrosis: outcomes and consequences. J Thorac Cardiovasc Surg. 2014;147(1):25-28.

76. Andrade PC, Flores GP, Uscello JeF, Miot HA, Morsoleto MJ. Use of iontophoresis or phonophoresis for delivering onabotulinumtoxinA in the treatment of palmar hyperidrosis: a report on four cases. An Bras Dermatol. 2011;86(6):1243-1246.

77. Vadoud-Seyedi J, Simonart T. Treatment of axillary hyperhidrosis with botulinum toxin type A reconstituted in lidocaine or in normal saline: a randomized, side-by-side, double-blind study. Br J Dermatol. 2007;156(5):986-989.

78. Güleç AT. Dilution of botulinum toxin A in lidocaine vs in normal saline for the treatment of primary axillary hyperhidrosis: a double-blind, randomized, comparative preliminary study. J Eur Acad Dermatol Venereol. 2012;26(3):314-318.

79. Kao MC. Laser endoscopic sympathectomy for palmar hyperhidrosis. Lasers Surg Med. 1992;12(3):308-312.

80. Austin JJ, Doobay B, Schatz SW. Transaxillary endoscopic laser sympathectomy. Can J Surg. 1992;35(4):414-416.

81. Kim IH, Seo SL, Oh CH. Minimally invasive surgery for axillary osmidrosis: combined operation with $\mathrm{CO} 2$ laser and subcutaneous tissue remover. Dermatol Surg. 1999;25(11):875-879.

82. Goldman A, Wollina U. Subdermal Nd-YAG laser for axillary hyperhidrosis. Dermatol Surg. 2008;34(6):756-762.

83. Ichikawa K, Miyasaka M, Aikawa Y. Subcutaneous laser treatment of axillary osmidrosis: a new technique. Plast Reconstr Surg. 2006;118(1): 170-174.

84. Bechara FG, Georgas D, Sand M, et al. Effects of a long-pulsed 800-nm diode laser on axillary hyperhidrosis: a randomized controlled half-side comparison study. Dermatol Surg. 2012;38(5):736-740.

85. Letada PR, Landers JT, Uebelhoer NS, Shumaker PR. Treatment of focal axillary hyperhidrosis using a long-pulsed Nd:YAG $1064 \mathrm{~nm}$ laser at hair reduction settings. J Drugs Dermatol. 2012;11(1):59-63.

86. Caplin D, Austin J. Clinical evaluation and quantitative analysis of axillary hyperhidrosis treated with a unique targeted laser energy delivery method with 1-year follow-up. J Drugs Dermatol. 2014;13(4):449-456.

87. Kotlus BS. Treatment of refractory axillary hyperhidrosis with a 1320-nm Nd:YAG laser. J Cosmet Laser Ther. 2011;13(4):193-195.

88. Aydin F, Pancar GS, Senturk N, et al. Axillary hair removal with 1064-nm Nd:YAG laser increases sweat production. Clin Exp Dermatol. 2010;35(6):588-592. 
89. Obeid G, Helou J, Maatouk I, Moutran R, Tomb R. Depilatory laser: a potential causative factor for inguinal hyperhidrosis: report of three cases. J Cosmet Laser Ther. 2013;15(5):286-289.

90. Hong HC, Lupin M, O'Shaughnessy KF. Clinical evaluation of a microwave device for treating axillary hyperhidrosis. Dermatol Surg. 2012;38(5):728-735.

91. Johnson JE, O'Shaughnessy KF, Kim S. Microwave thermolysis of sweat glands. Lasers Surg Med. 2012;44(1):20-25.

92. Suh DH, Lee SJ, Kim K, Ryu HJ. Transient median and ulnar neuropathy associated with a microwave device for treating axillary hyperhidrosis. Dermatol Surg. 2014;40(4):482-485.
93. Nestor MS, Park H. Safety and efficacy of micro-focused ultrasound plus visualization for the treatment of axillary hyperhidrosis. J Clin Aesthet Dermatol. 2014;7(4):14-21.

94. White WM, Makin IR, Barthe PG, Slayton MH, Gliklich RE. Selective creation of thermal injury zones in the superficial musculoaponeurotic system using intense ultrasound therapy: a new target for noninvasive facial rejuvenation. Arch Facial Plast Surg. 2007;9(1): $22-29$.

\section{Publish your work in this journal}

Clinical, Cosmetic and Investigational Dermatology is an international, peer-reviewed, open access, online journal that focuses on the latest clinical and experimental research in all aspects of skin disease and cosmetic interventions. All areas of dermatology will be covered; contributions will be welcomed from all clinicians and basic science researchers globally. This journal is indexed on CAS. The manuscript management system is completely online and includes a very quick and fair peer-review system, which is all easy to use. Visit http://www.dovepress.com/testimonials.php to read real quotes from published authors.

Submit your manuscript here: http://www.dovepress.com/clinical-cosmetic-and-investigational-dermatology-journal 